\title{
Effect of Picking Frequency on Yields and Quality of Intensively Managed Coffee ${ }^{1}$
}

\author{
Servando Silva, Fernando Abruña, and José Vicente Chandler ${ }^{2}$
}

\section{INTRODUCTION}

In Puerto Rico, coffee ripens irregularly and plantations are gone over several times during the harvest season, picking only ripe berries which are then processed by the wet method. However, during the last picking all remaining berries are stripped from the trees, and the ripe and green berries are either processed together by the dry method or separated mechanically and processed separately.

One way of increasing the efficiency of labor, which is often scarce during the harvest season, would be to reduce the number of pickings. This paper presents results of a study to determine the effect of frequency of picking on yields and quality of intensively managed coffee under typical conditions in the Coffee Region of Puerto Rico.

\section{MATERIALS AND METHODS}

This study was conducted during the 1965 and 1966 harvest seasons. Fiveyear-old Bourbon coffee trees, growing 4 feet apart in rows 10 feet apart in full sunlight, at an elevation of 2,600 feet on Los Guineos clay near Jayuya, were used in this experiment. The trees received intensive management, including application of 1 ton of 12-6-16 fertilizer per acre yearly, liming to pH 5.5, pest and weed control, and light annual pruning.

Picking dates, shown in table 1 , were selected on the basis of maturity of the crop. All treatments were replicated 10 times in a randomized block design using individual trees as plots.

Berries harvested from each tree at each picking were weighed and processed to determine yields of market coffee. After stripping, ripe and green berries were separated, processed, and the proportion of black immature berries determined.

\section{RESULTS AND DISCUSSION}

The proportion of green berries and the proportion of black, immature beans decreased significantly with an increased number of pickings, and

1 This paper covers work carried out cooperatively by the Agricultural Experiment Station, Mayagüez Campus, University of Puerto Rico, in Río Piedras, P.R. and the Soil and Water Conservation Research Division, Agricultural Research Service, USDA.

Agricultural Technician, Research Soil Scientist, and Research Soil Scientist (Project Leader), respectively, Soil and Water Conservation Research Division, Agricultural Research Service, USDA, stationed at Río Piedras, P.R. 
with delay in stripping. It seems likely that, with multiple pickings, less coffee is lost by dropping of overripe berries or picking of immature berries which produce worthless black beans.

Estimated value of the crop also increased from an average of $\$ 973$, when coffee was harvested in one operation (treatments 1 and 2), to $\$ 1,132$ with multiple pickings (treatments 3 and 4 ). In making these estimates it is assumed that all black, immature beans are removed, since they can otherwise greatly depress the value of the entire batch of coffee.

Whether the coffee trees were stripped in October or in November did not markedly affect total yields or estimated value of the crop (table 1 ).

TABLE 1.-Effect of picking frequency on yield and estimated value of crop produced by intensively managed Bourbon coffee at Jaynya; all values are averages of 2 crops

\begin{tabular}{|c|c|c|c|c|}
\hline \multirow{2}{*}{ Treatment } & \multicolumn{3}{|c|}{ Yields of market coffee llb./acre/year- } & \multirow{2}{*}{$\begin{array}{l}\text { Value of } \\
\text { crope in } \\
\text { dollars }\end{array}$} \\
\hline & $\underset{\text { berries }}{\text { From ripe }}$ & $\begin{array}{l}\text { From green } \\
\text { berries }\end{array}$ & Total & \\
\hline $\begin{array}{l}\text { 1. Stripped in middle of Oct. } \\
\text { 2. Stripped in middle of Nov. } \\
\text { 3. Picked in middle of Oct. and Nov.; } \\
\text { Stripped in middle of Dec. } \\
\text { 4. Picked } 3 \text { times as required, and then } \\
\text { stripped }\end{array}$ & $\begin{array}{r}470 \\
960 \\
1,320 \\
1,570\end{array}$ & $\begin{array}{r}1,060(19)^{3} \\
510(8.5) \\
390(5.1) \\
90(4.1)\end{array}$ & $\begin{array}{l}1,530 \\
1,470 \\
1,710 \\
1,660\end{array}$ & $\begin{array}{r}978 \\
969 \\
1,142 \\
1,123\end{array}$ \\
\hline L.S.D. 05 & 300 & $230(3.1)$ & N.S. & 一 \\
\hline
\end{tabular}

1 After discounting black, immature beans.

2 Beans from ripe berries at $68 \notin$ per lb. Beans from green berries at $64 \not k$ per lb.; includes additional cost of processing green berries.

- Numbers in parentheses show percent by weight of black, immature beans.

Stripping in October resulted in twice as many green berries, producing lower-priced beans, and twice as many worthless black beans from immature berries as did stripping in November. However, this apparently was offset by increased losses of overripe berries when stripping was delayed until November. Apparently, timing of the stripping operation within reasonable limits is not such a critical factor as it is generally believed to be.

Since picking is done on a piecework basis, it is to the farmers' advantage to continue with multiple pickings as long as sufficient labor is available. However, as labor becomes scarcer, the increased danger of losses from dropping of overripe berries may justify reducing the number of pickings to two or even one well-timed operation rather than three or four operations as at present.

Harvesting all the coffee in one or two operations could sharply increase 
labor efficiency and income, since a laborer engaged in stripping can harvest almost twice as much coffee as in picking. However, pickers would be employed for a shorter period on a given farm and would have to move from one farm to another and from lower to higher elevations following the ripening season.

Also, processing facilities would in some cases have to be expanded or worked more hours daily in order to handle the crop in a shorter period of time. This would not be a major problem with large processing facilities handling coffee from farms at varying elevations. Processing facilities would also require equipment to separate green from ripe berries and to remove black beans.

Number of flowerings, intervals between flowerings, rainfall, and other weather conditions affect the proportion of berries that is mature at any given time. Also, beans growing on trees in full sunlight mature earlier than shaded coffee, as shown by Abruña, et al. ${ }^{3}$, who also found that the Caturra variety matures later than the Bourbon variety. All these factors must be considered in deciding on the number of pickings.

\section{SUMMARY}

The effects of number of pickings on yields and quality of intensively managed Bourbon coffee were determined near Jayuya, Puerto Rico, over a 2-year period.

Similar yields of market coffee and estimated income were obtained when the coffee was harvested in one operation (stripping) in either midOctober or November. Thus, timing of this operation within reasonable limits does not appear to be particularly critical.

The proportion of green berries and of black beans decreased with number of pickings and with delay in stripping. A higher estimated income was obtained when the coffee was harvested in several pickings.

Although multiple pickings are more profitable at present, as labor becomes scarcer it may become desirable to pick coffee in two or even in one well-timed operation rather than in three or four as at present.

\section{RESUMEN}

Durante un período de 2 años se estudió el efecto que tuvieron el número de "cogidas" en la producción y calidad del café Bourbon cultivado in. tensivamente en la proximidad de Jayuya.

Se obtuvieron rendimientos estimados e ingresos comparables cuando

abruña, F., Vicente Chandler, J., Silva, S., and Gracia, W., Productivity of Nine Coffee Varieties Growing Under Intensive Management in Full Sunlight and Partial Shade in the Coffee Region of Puerto Rico, J. Agri. Univ. P.R., 49 (2): 244-53, 1965. 
toda la cosecha se hizo de una sola vez ("ripiando") bien a mediados de octubre o de noviembre, lo que indica, aparentemente, que no es de gran importancia que se fije una fecha precisa para la cosecha siempre que se haga dentro de límites razonables.

La proporción de granos verdes y/o negros disminuyó a medida que aumentaron las "cogidas" o se demoró el "ripio". Se obtuvieron mayores estimados de ingresos cuando la cosecha se hizo en varias "cogidas".

Aunque al presente es preferible hacer la cosecha en varias "cogidas", là recolección total puede que resulte más ventajosa en uno o dos "pases" antes que en tres o cuatro, si continúa acrecentán dose la escasez de obreros. 